UDC 37.018.5:005.32

NATALIIA HOI, Candidate of Economic Sciences, Associate Professor SHEI "Vasyl Stefanyk Precarpathian National University", Ukraine ORCID ID 0000-0001-7293-6527 natalygoy22@gmail.com OLHA ZHUK, Candidate of Economic Sciences, Associate Professor SHEI "Vasyl Stefanyk Precarpathian National University", Ukraine ORCID ID0000-0001-8519-5529 zhuk.oi82@gmail.com

\title{
WORLD EXPERIENCE IN IMPROVEMENT OF PEDAGOGICAL STAFF DEVELOPMENT MOTIVATION SYSTEM
}

\author{
НАТАЛІЯ ГОЙ, кандидат економічних наук, доиент кафедри \\ управління та бізнес-адміністрування, ДВНЗ "Прикарпатський \\ національний університет імені Василя Стефаника", Украйна \\ ОЛЬГА ЖУК, кандидат економічних наук, дочент кафедри управління \\ та бізнес-адміністрування, ДВНЗ "Прикарпатський національний \\ університет імені Василя Стефаника", Україна
}

\section{СВІТОВИЙ ДОСВІД УДОСКОНАЛЕННЯ СИСТЕМИ МОТИВАЦЇ̈ РОЗВИТКУ ПЕДАГОГІЧНОГО ПЕРСОНАЛУ}

The article highlights the topicality of using the world experience to improve the system of motivation for the teaching staff development. Authors emphasize the need to use various innovative methods and the best European practices in the management process of educational institutions; emphasize the numerous opportunities and new mechanisms for teachers' professional development that provide ways to motivate employee development. The article partly describes the foreign experience of using innovations in improvement of educator development motivation system. Authors analyze the tools for motivating the teaching staff development: identifying categories of employees, in particular, "innovators" and "pioneers" for further work with them, conducting competitions for the best blended learning type projects, creating a success situation and teaching staff encouragement system. Researches claim that the activity of educational institutions in the terms of reform requires the innovative and active behavior of the staff and development of their creative abilities.

(C) N. Hoi, O. Zhuk
Key words: development motivation system, teaching staff, management innovations, educational institution.

Анотація. У статті висвітлюється актуальність питання використання світового досвіду удосконалення системи мотивації розвитку педагогічного персоналу. Автори акцентують увагу на потребі різноманітних інноваційних методик та передових європейських практик в управлінському процесі закладів освіти; численних можливостях і нових механізмах професійного зростання вчителів, які передбачають шляхи мотивації розвитку працівників. У статті частково описано зарубіжний досвід використання інновацій удосконалення системи мотивації розвитку педагогів. Автори аналізують інструменти мотивації розвитку педагогічного персоналу: визначення категорій працівників, зокрема, "новаторів" та "піонерів" для подальшої роботи з ними, проведення конкурсів на кращі проекти змішаного навчання, створення ситуації успіху та системи заохочення педагогічних працівників.

Ключові слова: система мотивації розвитку, педагогічний персонал, інновації управління, заклад освіти.

Мета: провести аналіз використання світового досвіду удосконалення системи мотивації розвитку педагогі- чного персоналу.

General problem setting. The working activity of educational institutions in the reform context requires innovative and active behavior of staff, development of their creative abilities. The innovative development of modern institutions of general secondary education is impossible without the formation of innovative thinking of staff. It requires a qualitatively new approach to the formation of a motivational mechanism. Unlike traditional approaches to human resource management, the managers of modern educational institutions should activate the innovative behavior of teaching staff, create conditions for their professional and creative development and apply advanced approaches to motivation system.

Analysis of researchers and publications. The implementation and development of innovative educational technologies require the study of psychological and pedagogical factors that influence the readiness of teachers to professional growth as the key component of the educational institutions strategy success depends on the teachers desire to professional development (School management, 2019).

Most educators are not ready for the 


\section{Table 1}

Ways to improve the system of staff development motivation

\begin{tabular}{|c|c|c|}
\hline Stage & Task & Stage values \\
\hline 1 stage & $\begin{array}{l}\text { Identify four groups of educators within the institution. } \\
\text { This can be done through questionnaire and } \\
\text { interviewing. } \\
\text { Key questions of the questionnaire can be the } \\
\text { following: } \\
\text { Have teachers taken initiatives to learn innovative } \\
\text { tools? } \\
\text { What were the results? } \\
\text { What resources were used? } \\
\text { Were there any innovative ideas that could not be } \\
\text { implemented? } \\
\text { Could this idea be implemented under certain } \\
\text { circumstances (availability of development team, } \\
\text { resources, time)? } \\
\text { What is the reason for the failure of innovative } \\
\text { projects? }\end{array}$ & $\begin{array}{l}\text { At this stage, it is important to think over the } \\
\text { mechanisms for the voluntary participation of } \\
\text { teachers in the questionnaire. Advisable to send } \\
\text { informational messages to all participants of the } \\
\text { survey before conducting the testing procedure. } \\
\text { Such messages should inform educators about the } \\
\text { purpose of the survey, describe in detail the idea and } \\
\text { basic principles of innovative technologies, and } \\
\text { emphasize the importance of introducing } \\
\text { innovations and the importance of each employee } \\
\text { for the educational institution. }\end{array}$ \\
\hline 2 stage & $\begin{array}{l}\text { Conducting competitions for the best project, creating a } \\
\text { success situation. The results of the survey, obtained } \\
\text { during the first stage, make it possible to identify } \\
\text { educators who are actively innovating in the learning } \\
\text { process. However, their skill level can be seen only by } \\
\text { the example of complex project work. The project may } \\
\text { reflect the ideas of one or mo re authors who have } \\
\text { ambitious ideas and are ready to present them to the } \\
\text { public. Thus, it is possible not only to stimulate the } \\
\text { creative abilities of the most active educators, but also } \\
\text { to spread this idea at the level of the whole institution. }\end{array}$ & $\begin{array}{l}\text { When selecting project ideas, you also need to pay } \\
\text { attention to such criteria as the innovative nature of } \\
\text { the idea, the resources needed for its } \\
\text { implementation, the strategy for its implementation } \\
\text { and efficiency. } \\
\text { An important final point will be the awarding the } \\
\text { winners with bonus, prizes, certificates of honor and } \\
\text { other promotional to ols as well as the coverage of } \\
\text { this event on the educational institution website. } \\
\text { This fact will create a situation of success and a } \\
\text { sense of satisfaction for their achievements, make } \\
\text { them proud for their cause, self-respect. }\end{array}$ \\
\hline 3 stage & $\begin{array}{l}\text { Creation of a system for encouraging pedagogical } \\
\text { workers to implement ideas for professional } \\
\text { development. }\end{array}$ & $\begin{array}{l}\text { The promotion systems include individual ratings of } \\
\text { the teaching staff, awarding "quality marks", } \\
\text { promotion of pedagogical innovation, informal } \\
\text { communication with colleagues who have } \\
\text { experience in implementing innovative technologies. }\end{array}$ \\
\hline
\end{tabular}

* Source: author's own development.

changes because the process of staff formation in educational institutions is established and conservative for a long time. Making adjustments to practical activities, updating working tools, introduction of new technologies requires personal desire and stimulation, influence of topical motivational factors that encourage professional growth (Kosenko, 2019). Accordingly, all innovations in the reforming process of the educational sector will be useless unless the concept of professional activity motivation and stimulation of teachers on the basis of innovation is defined (Bobrovsky, 2019, p. 53).

Scientists have identified the motivation system of staff development as a system of determinants, causes, incentives, motives, which encourages educators to professional growth; motivation is seen as a system of ideas and beliefs, feelings and experiences that express the material, spiritual, natural, cultural needs of the individual; just awareness of needs and incentives for satisfaction of professional growth creates a general mechanism for motivating the educator development (Kremin', 2008, p. 528).

Foreign scientists traditionally divide motivation into internal and external. Exactly internal motivation determines the importance of professional development process, serves as a source of inspiration and satisfaction in terms of personal needs (for example, creative realization, enhancement of competence). External motivation is driven by material incentives from the outside and aimed for achieving positive results (e.g. career, money value, awards, etc.). Teachers motivated by internal factors defined as "enthusiasts". They enjoy the process of learning, communicating with students and colleagues, interested in the continuous improvement of their own professional skills and professional results, open for new ideas and mostly initiate their implementation. Enthusiasts are usually presented in any organization, but they are an absolute minority. They are the exact innovators that can bring significant benefits to their organization through their creative ideas.

Outline of the main research material. The main task of management in an educational institution is to find the hidden potentials and to use them skillfully for development both an educational institution and the 


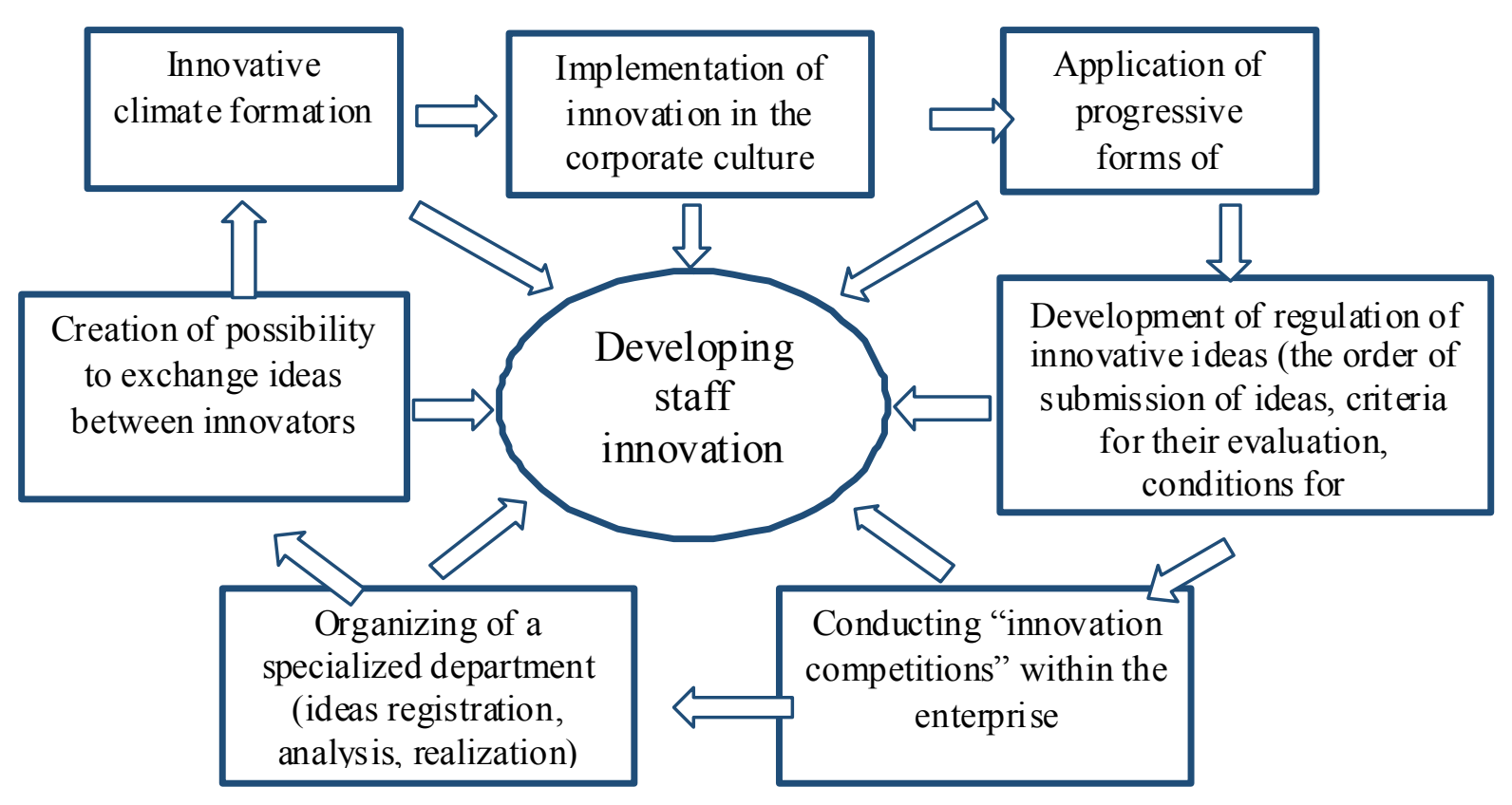

\section{Fig. 1. Systematic measures of teaching staff motivation \\ * Source: authors' development.}

educators themselves. Effectively combining internal and external factors of personnel development motivation with skillful management of innovations, the management of the general secondary education institution can significantly increase the efficiency of pedagogical activity (Vishnevskaya, 2016, p. 142).

In his research, J. Staes, a popular Belgian expert on motivational innovation in educational institutions, emphasizes fundamentally new bottomup approaches in any organization, using an interesting metaphor for new ideas - the red monkeys (Staes, 2017). The scientist believes that new ideas "red monkeys" - are emerging between the representatives of different ecosystems in the process of exchange of thoughts. An emerging innovation will attract attention in its natural habitat (jungle) and find followers or opponents. According to teachers' attitude to innovation of development motivation, therefore J. Staes recommends to distinguish four categories:

- "creators": educators who generate new ideas but cannot implement them on their own;

- "pioneers": Allies of innovators who have the time, desire and resources to develop and implement those ideas. They can realize the innovators' idea;

- "followers": those who do not have much inspiration for innovation but are ready to implement it if innovations are tested by the pioneers and will benefit them;

"settlers": conservatives, opponents of change. On the one hand, they are necessary for system stability, but on the other hand, they will be forced out of the organization if global changes occur.

According to J. Staes, the success of the development of the organization and, accordingly, the introduction of innovations lies precisely in the conflict between "innovators" and "settlers". The consensus model in which education staff are satisfied with the current situation does not motivate innovation. According to Staes's argument, the following ways of motivating staff development in general secondary education institutions can be recommended as shown in Table 1.

The approval by the public of their own initiative increases the efficiency and quality of the pedagogical employee work, creates positive motivation in the process of achieving the goals (Redko, 2015, p. 32). However, the main reward for the teacher-innovator will be the opportunity, not so much to gain recognition at the educational institution level, such as to realize their idea and to see it works and in professional growth. Any new pedagogical technology needs a specific approach.

However, human resources are crucial for successful innovative staff development in general secondary education institutions. The methods and stages of motivation development for educators presented by the author represent a small part of possible influences and incentives, but their realization can significantly influence the speed and activity of applying new pedagogical ideas.

Scientists believe that innovative staff are different from ordinary staff in the following features: high professional competence, independence, initiative, entrepreneurship, activity, creativity, innovation, originality at work, ability to bring an innovative idea to implementation, perseverance, ability to perform international functions standards, high adaptation capacity, and high level of culture (Kuznetsova, 2009, p. 118).

The success of the innovative process depends on the fact as far the direct participants in the innovative process are interested in the rapid implementation of the know-how in the educational process. In this regard, stimulation of innovative professional activity should be based not only on material, but also on non-material (sociopsychological) forms of stimulation, focused on meeting the needs of the teacher's personal growth. The scientists emphasize that staff motivation to innovative activity has its own peculiarities and the need to develop methodological foundations for 
creating an appropriate motivation development mechanism as a tool for activating employees' innovative behavior (Monastirskaya, 2009, $p$. 210).

But for the lack of necessary institutional changes and poor motivation, the labor behavior of the majority of the able-bodied population of Ukraine remains passive and is characterized by the expectation of the results of further economic and social reforms. Differently new changes in the attitude of the staff to quality are hampered by inadequate motivation and qualification of specialists. Crisis economic phenomena do not contribute to the systematic knowledge updating, the desire to improve the employees' skills, there is an outflow of skilled personnel abroad. The experience demonstrates that the educational institutions staff in Ukraine is not ready to use different types of innovations and for the most part is a deterrent to innovation. The experts in the field of pedagogical management believe that this is due to the fact that the teaching staff has a fear of changing the usual way of work, unwillingness to make efforts for additional training without significant material incentives.

Creativity and innovation, which will make the educational service unique, give them excellent quality and competitive advantages largely depend on the teaching staff in general secondary education institutions. Therefore, the management of the educational institution should try to meet the needs and expectations of its teaching staff in recognizing and receiving satisfaction from work as well as in their development. In order to encourage pedagogical staff to constantly improve their skills, we propose the following management measures in general secondary educational establishments:

- planning and ensuring continuous training and career development;

- creating conditions that encourage the development and implementation of innovations;

- conducting a systematic analysis of teachers' professional needs;

- various recognitions and material rewards;

- providing conditions for effective teamwork;

- precise defining of the powers and responsibilities of the staff;

- elaborating of personal and collective development goals, management of improving process and evaluation of results;

- analysis of teachers' satisfaction level and improvement of approaches to increase the level of personal development motivation;

- analysis of staff turnover, improvement of the recruitment and placement employee process.

A big part of the teaching staff is able to make a valuable contribution to the expansion of the educational institution development strategy. Figure 1 displays the systematic measures that allow maximum use of the creative ideas of pedagogical workers and develop their innovative tendencies and personal improvement.
Motivation can be considered as creating the conditions for all-round encouragement, the promotion of teaching staff to professional activities aimed at achieving the strategic goals of the institution of secondary education. The incentive system should also include the obligatory encouraging the development of creative abilities of teaching staff, the generation of creative ideas which is a prerequisite for innovation. Teachers' effectiveness in implementing innovation depends on the fact as much the instant participants of the process are interested in the speed of getting the result. It should be noted that the methods of individual and group motivation of staff development to innovative activity have certain features (Table 2).

In order to build an effective system of personnel motivation for creativity and initiative in creating innovation, it is necessary to harmonize individual and group motivation. The process of forming motives and stimulating innovative staff meets the basic principles of work motivation, but it has its own peculiarities: stimulating creativity, independence, creativity, responsibility. It should be noted that the motivation to innovate should be a long-term nature, otherwise it becomes impossible to implement strategic innovation plans designed for a long term. To create certain long-term orientations in the professional activities of teaching staff, preference should be given to positive motivational factors or incentives rather than negative ones (anti-incentives, such as

Table 2

Comparison of individual and group pedagogical staff development motivation

\begin{tabular}{|c|c|c|}
\hline $\begin{array}{l}\text { Comparative } \\
\text { signs }\end{array}$ & Individual motivation & Gro up motiva tion \\
\hline Goal & $\begin{array}{l}\text { The purpose of self-expression, } \\
\text { personality's creativity }\end{array}$ & $\begin{array}{l}\text { A common goal, the formation of a team of creative } \\
\text { professionals }\end{array}$ \\
\hline Image & Position, prestige, pride & Pride for the team, formation of innovative culture \\
\hline Career Growth & Educator career development & $\begin{array}{l}\text { The status change of the unit and management depending } \\
\text { on the success of the innovation }\end{array}$ \\
\hline Working Conditions & $\begin{array}{l}\text { Self-development right, creative } \\
\text { business trips, flexible schedule }\end{array}$ & $\begin{array}{l}\text { Encour aging the group work, free exchange of views } \\
\text { between the manager and subordinates }\end{array}$ \\
\hline Material promotion & One-time awards, bonuses & One-time awards, bonuses \\
\hline $\begin{array}{l}\text { Non-Material } \\
\text { promotion }\end{array}$ & $\begin{array}{l}\text { Regulation of the teacher's behavior } \\
\text { based on the feeling of his / her } \\
\text { satisfaction with the realization of } \\
\text { creative abilities and ideas }\end{array}$ & $\begin{array}{l}\text { Expanding the innovative capacity of the educational } \\
\text { organization and enhancing its competitiveness }\end{array}$ \\
\hline
\end{tabular}


sanctions, restriction of independence, punishment). It is necessary to consolidate in the employee's working consciousness the hope for success, confidence in the support and encouragement of creative search by the educational institution administration. (Kapinos, 2008, p. 121).

The research shows that in order to successfully adapt to the dynamic changes of the environment it is necessary to constantly implement innovative processes in general secondary education institutions aimed to meet the new needs of consumers and increasing the competitive advantages of the organization. The focus on innovation should be present in the activities of managers at all levels of government. In order to accomplish this task effectively, the modern manager of an educational institution must react quickly and be able to make optimal decisions in difficult non-standard situations and possess new methods of management. Thus, a modern manager should have a developed innovative thinking. Let us consider the main tasks of an educational manager with an innovative type of thinking:

- rallying around the innovative activity the creative and capable specialists;

- creating of a comprehensive system of teachers' motivation for the development and implementation of new ideas, projects, non-standard solutions;

- forming an innovative climate that will encourage staff to acquire new knowledge, offer creative solutions, take care of the prestige and competitiveness of the educational institution;

- evaluation of the innovative measures effectiveness, innovations implementing.

The motivational mechanism for engaging staff to innovate will be effective when it is based not on the ground of administrative influence but on a socio-economic leverage. This will enable the management process to be carried out on the principle of selfregulation.

Conclusions and perspectives for further research. The activity of educational institutions in the context of reform requires innovative and active behavior of staff, development of their creative abilities. The innovative development of modern general secondary education institutions is impossible without the formation of innovative thinking in staffand requires a qualitatively new approach to the formation of a motivational mechanism. Combining different methods of stimulation, working with staff to identify their motivational factors will promote the development of educators' professional skills, development strategies implementation in secondary educational institutions.

\section{REFERENCES}

Bobrovsky, M. V, Gorbachev, S. I. \& Zaplotinskaya, O. O. (2019). Recommendations for the establishment of an internal quality assurance system for general secondary education. Kyiv, State Service for the Quality of Education.

Kapinos, G.I., Zlobina, I.S. (2008). Stimulation of employees in the conditions of innovative development of economy of Ukraine. Science and Economics, 4 (12), 119-123. (in Ukrainian)

Kosenko, D. (2019). The New Educational Space: Information Handbook. Retrieved from https:// storage.decentralization.gov.ua/ u p loads/1 ibrary/fi le/40 7 / NOP_Motivuyuchiy-prostir.pdf

Kremin', V.G. (ed.) (2008). Encyclopedia of Education, Academy of Ped. Sciences of Ukraine. Kyiv: Yurinkom Inter, 2008, 1040 p. (in Ukrainian)

Kuznetsova, N. B. (2009). Personnel of innovative type: essence, meaning and features of formation in conditions of development of innovative economy, Economics and enterprise management, 6 (96), 115-121. (In Ukrainian)

Monastirskaya, G.V. (2009). The mechanism of motivation of innovative activity at the enterprise. Bulletin of the Donbass State Machine-Building Academy, 2(16), 207-212. (In Ukrainian)

Redko, S.I., Panchenko, A.G. (2015). Investigation of motivational sources of pedagogical workers as a factor of success of a comprehensive educational institution. Pedagogical process: theory and practice, 3-4, 29-34. (In Ukrainian)

School management. Workshop (2019) EdEra Online Education Studio. Retrieved from https://courses.edera.com/courses/course-v1:EDERAPROSVITCENTER+SM101+sm101/ about

Staes, J. (2017). The Red Monkey Story - or How to Manage Creative Ideas. Retrieved from https:// w w w . y o u t u b e c o m/ watch? $\mathrm{v}=\mathrm{BFk} 4 \mathrm{dCC}$ wlRg.

Vishnevskaya, O. \& Hoi, N. (2016). An innovative approach to preschool educational management. Mountain School of the Ukrainian Carpathians, 15, 140-144. Doi 10.15330/ msuc.2016.15.140-144 (in Ukrainian)

Стаття надійшла 12.04.2020р. 